\title{
Refuge
}

Canada's Journal on Refugees

revue canadienne sur les réfugiés

\section{The Child in International Refugee Law, by Jason M. Pobjoy}

\section{Geraldine Sadoway}

Volume 34, Number 1, 2018

Intersectional Feminist Interventions in the "Refugee Crisis"

URI: https://id.erudit.org/iderudit/1050859ar

DOI: https://doi.org/10.7202/1050859ar

See table of contents

Publisher(s)

Centre for Refugee Studies, York University

ISSN

0229-5113 (print)

1920-7336 (digital)

Explore this journal

Cite this review

Sadoway, G. (2018). Review of [The Child in International Refugee Law, by Jason M. Pobjoy]. Refuge, 34(1). https://doi.org/10.7202/1050859ar

Copyright (c) Refuge: Canada's Journal on Refugees, 2018

Creative Commons Attribution NonCommercial 4.0 International License

\section{(c) (7) (8)}

This document is protected by copyright law. Use of the services of Érudit (including reproduction) is subject to its terms and conditions, which can be viewed online.

https://apropos.erudit.org/en/users/policy-on-use/ 
also chapter 7, which documents "innovations on the run." This chapter really demonstrates the operational flexibility demanded during that period and how public servants had to draw inspiration from unexpected places (e.g., the Berlin airlift) to respond to the new challenges they faced. Section 2 provides a vivid and diverse portrait of the day-to-day work over this period. Using interviews, narratives, and even original reports produced in the field, chapters in this section highlight the complexity of the work of these officers in relation to headquarters' (Ottawa) misunderstandings of the realities in the field, lack of resources, but also simple human factors that affected the officers' working conditions. The inclusion of a chapter on Quebec's operations in Southeast Asia is a commendable contribution to our understanding of the lesser known actions of the province during that period. This section is the most original of the book. At the same time, it could have benefited from a richer discussion regarding the decisions of what to include in this section, e.g., specific issues and events. Likewise, more contextualization of the individual narratives included would have been helpful. Section 3 focuses on the resettlement operations as they unfolded in Canada. It includes accounts of arranging the operations at the airport, coordination between government stakeholders, and the work of the refugee settlement officers. Running on Empty also includes a useful chronology of the Indochinese refugee movement to Canada, pictures of the operations, maps of the areas described, and biographies of all of the officers who shared their experience. It concludes with some lessons learned from this extraordinary operation.

Running on Empty is hesitant to make any theoretical claims and resists making strong political statements. While this may be frustrating for some readers, it should also be seen as an opportunity. It provides scholars with a wealth of empirical information and testimonies to build on. It also shows the lasting influence of this period on current policies and operations, despite legislative changes and new technologies. It is a timely publication, as Canada is now starting to take stock of the 2015 Syrian resettlement initiative. Parallels and contrasts can be drawn throughout the book. The most important being, undoubtedly, that the "size of the commitment [to resettle Indochinese refugees] came as a surprise to public servants" (454), something that is reminiscent of Trudeau's post-election commitment to resettle 25,000 Syrian refugees in a year. While technologies, the size of the federal administration, and the overall geopolitical context have evolved, chances are that the future work on the 2015 episode will stress similarities with the 1975-80 period such as innovation despite limited resources, officers' dedication in the field, and the contribution of the private sponsorship program. At the same time, the book is a sobering reminder not to prematurely celebrate Canada's current resettlement efforts. Considering the major differences that are the unprecedented size of global displacement and growth of the capacity of the Canadian state, the story told by Running on Empty makes the 2015 resettlement targets less impressive, to say the least.

Mireille Paquet is an assistant professor of political science at Concordia University and the co-director of Concordia's Centre for Immigration Policy Evaluation. She can be contacted at mireille.paquet@concordia.ca.

\section{The Child in International Refugee Law

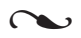 \\ Jason M. Pobjoy \\ Cambridge: Cambridge University Press, 2017, 317 pp.}

I $\mathrm{n}$ his magnificent new book Jason M. Pobjoy methodically and persuasively builds the case for a thorough reset of international refugee law in order to address the gap in protection for refugee children. Despite the fact that almost half of the world's refugees are children, refugee law tends to make them invisible, using an adult-centred lens that fails to capture the predicament of children and youth who are refugees, resulting in incorrect assessments of refugee status.
(C) Author(s), 2018. This open-access work is licensed under a Creative Commons Attribution-NonCommercial 4.o International Licence, which permits use, reproduction, and distribution in any medium for non-commercial purposes, provided the original authorship is credited and the original publication in Refuge: Canada's Journal on Refugees is cited.
Cette ouvre en libre accès fait l'objet d'une licence Creative Commons Attribution-NonCommercial 4.0 International License, laquelle autorise l'utilisation, la reproduction et la distribution de l'œuvre sur tout support à des fins non commerciales, pourvu que l'auteur ou les auteurs originaux soient mentionnés et que la publication originale dans Refuge: revue canadienne sur les réfugiés soit citée. 
If they are accompanied by adults, children's claims are often treated as derivative, accepted or rejected based on the adults' claims, when in fact a child often has independent grounds for refugee status. As Pobjoy's analysis shows, recognizing the plight of refugee children does not involve watering down the Convention definition of refugee, but rather bringing it into line with developing international human rights law, and upholding the basic refugee law principle of non-refoulement. $\mathrm{He}$ also clearly demonstrates how the "best interests of the child" principle, as set out in the Convention on the Rights of the Child (CRC), can be used as a separate and complementary legal basis for protection of refugee children and youth, preventing their deportation if contrary to their best interests.

This book is an essential resource for refugee decisionmakers, policymakers, and advocates. It comprehensively reviews the legal scholarship on the Refugee Convention as it relates to children, going back to the seminal works of Grahl-Madsen, Goodwin-Gill, and Hathaway, and the ground-breaking comparative research study on the treatment of separated and unaccompanied refugee children in the United States, the United Kingdom, and Australia by Bhabha, Crock, Schmidt, and Finch. ${ }^{1}$ Pobjoy reviews UnHCR's accomplishment over the past thirty years in developing guidelines for the application of the Refugee Convention to children, and in promoting the Convention on the Rights of the Child as the fundamental legal framework for the protection of children and adolescents. Most significantly, Pobjoy exhaustively reviews the development of international and domestic case-law dealing with the determination of refugee status of children, quoting from decisions of the highest courts in the United Kingdom, the United States, Canada, Europe, Australia, and New Zealand. While researching this book he identified and reviewed over 2,500 refugee decisions involving children, and he has indexed and captured these cases in a web resource.

The foundation for Pobjoy's thesis is set out in the first chapter, beginning with the historical background of the refugee child's place in international human rights law from the 1924 Declaration on the Rights of the Child to the 1989 Convention on the Rights of the Child.

The CRC provides a principled basis for child-appropriate procedures in adjudicating refugee claims involving children. Realizing the participatory rights of children in refugee determination is the first step to countering their invisibility. Children's claims are more likely to be ignored when they are accompanied by their parents. Pobjoy discusses the inadequacy and asymmetry of derivative refugee status that often occurs with accompanied children, even when the child is the principal applicant with the strongest claim for protection. This also leads to asymmetry in refugee settlement. For example, in Canada adult refugees are permitted to include their non-refugee family members in their request for permanent resident status in order to maintain family unity. However, refugee children are not permitted to include their parents and siblings in their application for permanent residence and are often denied family reunification. Counsel have dealt creatively with the adult-centred refugee status determination by arguing that the parent should be granted refugee protection because the parent is at risk of psychological harm due to the harm that would befall the child. Pobjoy shows that reliance on the specific human rights of children set out in the CRC could result in a more principled approach to refugee determination of all family members, overcoming the asymmetry of adult-centred derivative refugee status.

The CRC is also an interpretive aid for dealing with refugee claims by children and youth, as it creates a child-centred lens for the Refugee Convention. This is relevant in addressing subjective fear of persecution, credibility assessment, and the increased fact-finding responsibility of the decision-maker when dealing with child claimants. The child-centred lens of the CRC also focuses on the myriad variety of serious harms that constitute persecution of children. Pobjoy illustrates these persecutory harms with case studies that connect to the fundamental human rights of children as set out in the CRC. Although some of these particular harms may not be persecutory for adults, they are persecutory for children as a result of their emotional and physical dependency, their developmental needs, and their greater sensitivity and vulnerability.

The complex issue of "nexus to Convention grounds" is explored in detail as it relates to the refugee status of children. Pobjoy shows how the "predicament of the claimant" approach is more appropriate for identifying the nexus to Convention grounds in claims by children. In the situation of harm from non-state actors, including the family of the child refugee, the CRC provides guidance on effective state protection. Furthermore, the reasons for the well-founded fear of persecution may be related to the "particular social group" of childhood, or the family of the child claimant.

Perhaps the most interesting and innovative part of this book is the analysis and discussion of how the Convention on the Rights of the Child provides additional and complementary grounds for protection of the child. The application of the best interests principle to all judicial and administrative decisions concerning the child, when combined with the clearly stated human rights of the child as set out in the CRC, can be used to prevent the deportation of a child who may not qualify for refugee protection.

This book is a valuable and timely resource. Pobjoy makes a principled, transparent, and sophisticated argument for increased protection of refugee children by using the CRC. Refugee advocates are encouraged to have recourse to the un Committee on the Rights of the Child, which has a clear 
mandate to monitor state compliance with the Refugee Convention as it applies to children and youth. And Pobjoy demonstrates that state failure to comply with commitments under the Convention on the Rights of the Child results in violation of the Refugee Convention by refoulement of refugee children. This book and the website resource constitute a monumental achievement that will have a significant impact on the developing law and will act as a major force in filling the protection gap for refugee children.

\section{Note}

1 See J. Bhabha and Susan Schmidt, "Seeking Asylum Alone: Unaccompanied and Separated Children and Refugee
Protection in the U.S." (Cambridge, MA: Human Rights at Harvard, June 2006); J. Bhabha and Nadine Finch, "Seeking Asylum Alone: Unaccompanied and Separated Children and Refugee Protection in the U.K." (Cambridge, MA: Human Rights at Harvard, November 2006); J. Bhabha and Mary Crock, Seeking Asylum Alone-A Comparative Study: Unaccompanied and Separated Children and Refugee Protection in Australia, the UK and the Us (Sydney: Themis, 2007).

Geraldine Sadoway is a lawyer affiliated with Osgoode Hall Law School, York University. She can be reached at gsadoway@ gmail.com. 